\title{
Islamophobia in Spain: Inheritance of Reconquista and Hate Political Rhetoric
}

\author{
Farkhani, ${ }^{*}$ Zakiyuddin Baidhawy ${ }^{* *} \&$ Adang Kuswaya ${ }^{* * *}$
}

\begin{abstract}
The article discusses the development of Islamophobia in Spain and the connection with the ruling of Islam in Andalus, including the impact of Reconquista (re-conquest) that was followed by inquisition; and the connection between Islamophobia and the changing orientalist tradition which impact social and political constellation in Andalus and the West in general up to Post 9/11. Employing a qualitative approach, this study shows that the rise of Islamophobia in Spain in the modern-contemporary era is enabled through the rise of populist politics in Europe in general. Populist rhetoric revives the memories of Islamic domination in Andalus and Reconquista to win votes. Islamophobia is also worsened by Islamophilia - uncritical admiration of the values of Islam, generally associated with an admiration of Islamic civilization and Maurophilia - the explicit romanticization of the Moors in Spanish literature and the complex, often silent presence of Moorish forms in Spanish material culture. This study also demonstrates that hate rhetoric towards Islam in contemporary era is highly influenced by the development of American Orientalism model motivated by war or revenge against terrorism.
\end{abstract}

Keywords: Islamophilia, Maurophilia, Populism, American orientalism

\section{Introduction}

There is always a pivotal momentum in the history of humankind to end or begin a new milestone. This is also the case with the rise of Islamophobia which was always linked to the development of orientalism from the classic era to neo-orientalism. The momentum was the terror attack in Manhattan, the bombing of WTC on September 11,2001. The tragedy triggered the memory, prejudices, and hate towards Islam and Muslim in the West-U.S. and Europe especially. It is referred to as Islamophobia, something considered normal in all layers of Western society. ${ }^{1}$ Islamophobia also happens to upper classes to even the political elites in Western countries. It's to be noted that Islamophobia has spread to even the highest positions in their government. Similar things also happened in the upper level of society up to the political elite in Western countries. It can be noted that Islamophobia has penetrated to the highest positions of their government. ${ }^{2}$ For example, a recent study has shown that almost all the countries that are part of the European Union, right-wing parties, and those who have power in parliaments of European countries and European Parliament itself, have presented an Islamophobic mantra. ${ }^{3}$

This article will examine how far Islamophobia has grown in contemporary Spain as an implication from Islam domination in a part of Andalusia ${ }^{4}$ for approximately 7 centuries. Also its relations with the Reconquista (Re-conquest) that was followed by the Inquisition; and its relation to the tendencies of orientalism tradition that continues to grow, change and influence the socio-political constellation in Andalusia, and the West in general, even after the 9/11 tragedy.

Before proceeding with the discussion mentioned above, the author will explain the importance of clarifying several key issues related to Islamophobia. There have been significant debates on this term and it's meaning in recent years. ${ }^{5}$ Those debates stretch from academics to non-academics' practitioners

\footnotetext{
${ }^{*}$ Farkhani, Lecturer, State Institute of Islamic Studies (IAIN) Salatiga, Indonesia. Email: farkhani1976@yahoo.com.

** Zakiyuddin Baidhawy (Ph.D), Professor, State Institute of Islamic Studies (IAIN) Salatiga, Indonesia. Email: zbaidhawy@ gmail.com.

*** Adang Kuswaya, Lecturer, State Institute of Islamic Studies (IAIN) Salatiga, Indonesia. Email: dangkuswaya@ gmail.com.

1 The Runnymede Trust (1997), "Islamophobia: A Challenge for Us All: Summary," retrieved 14 ${ }^{\text {th }}$ December 2020, https://www.runnymedetrust.org/uploads/publications/pdfs/islamophobia.pdf.

2 Jocelyne Cesari (2004), When Islam and Democracy Meet: Muslims in Europe and in the United States, New York, NY: Palgrave Macmillan, p. 41.

${ }^{3}$ Zuhal Yesilyurt Gunduz (2010), "The European Union at 50 - Xenophobia, Islamophobia and the Rise of the Radical Right," Journal of Muslim Minority Affairs, Vol. 30, No. 1, pp. 35-47.

${ }^{4}$ Al-Andalus (in Arabic: الأندلس, translit. Al-andalus) is the name of the part of the Iberian Peninsula (Spain and Portugal) which was ruled by the Muslims, or the Moors between 711 and 1492. Al-Andalus is also often called Andalusia, but this usage has ambiguity to the administrative regions of Andalusia in modern Spain. John L. Esposito (ed.) (2003), Oxford Dictionary of Islam, Oxford Reference Online, Oxford University Press, 2003, entry Andalus, al-.

${ }^{5}$ Chris Allen (2010), Islamophobia, Farnham: Ashgate; John L. Esposito and Ibrahim Kalin (2011), Islamophobia: The Challenge of Pluralism in the 21st Century, Oxford: Oxford University Press; Scott Poynting, Victoria Mason (2007), "The Resistible Rise of Islamophobia: Anti-
} 
who on one hand are passionate in exposing Islamophobia, while on the other hand criticize and corner this term. In this chapter the author does not see Islamophobia as a criticism towards Islam as a religion because a criticism towards religion does not have to be based on prejudice. Here, Islamophobia is seen as an attempt to demonize Islam and / or Muslims using stereotypes that has been believed in history. These stereotypes believe that Islam or Muslims are oppressive, barbaric, and violent. Islamophobia has the same sense with racism for the reason that it essentially sees a group of people as having inherited traits as an inferior being. Some scholars suggest using alternative terms for Islamophobia such as "anti-Muslim racism" or "Muslimophobia." But in this section the author is more inclined to use the term Islamophobia because it's more comprehensive than the other terms.

In fact, according to Brian Klug, ${ }^{6}$ Islamophobia is a term that has been widely accepted and used by academics and in main discussions as a concept that has been understood rather than challenged. Some of the main criticisms of the term Islamophobia are actually related to their literal meaning, which can be problematic including the believe that using the term "against Islam" is a mistake and that it is not a phobia. The point is that the West sees Islam / Muslims as "different" or "the other group" and build stereotypes of Islam / Muslims as human beings with negative inner qualities.

According to Laura Cervi, ${ }^{7}$ in the context of the development of populism and Islamophobia in Europe, particularly in the case of Spain and Italy, Islamophobia can be divided into two types. First, "banal Islamophobia," which is a bad and distant perception that is closely related to anti-Islam (foreign) sentiments. This perception grows from feelings that Westerns are different from Muslims and their stereotypes about Muslims -- in physic, dress, daily habits, and religious beliefs. Muslims are seen as deviating from what is considered "normal" in the native community, so there is emotional distance and Western perceives them as a threat. In this sense "banal Islamophobia" seems to have its roots in Orientalism. Second, "ontological Islamophobia," namely the perception that views Islam as an external threat, sees Islamic civilization as monolithic, and a threat to the democratic order of Western society. This Islamophobia is rooted in the theory of "the clash of civilization," ${ }^{8}$ which describes the entire Islamic civilization as ontologically incompatible with core Western values. Therefore, distinguishing between "banal" and "ontological" Islamophobia is very useful operationally for analyzing and showing how the various articulations of Islamophobia exist or coexist and how each of these articulations of them, or mixtures thereof, function to achieve different types of political mobilization.

The tendency of Islamophobia subtly developing among the highly educated and high-status elites in society is very dangerous. It's because the elites can formulate and spread Islamophobia and racism to the grassroots society so it becomes more vulgar and violent. ${ }^{9}$

\section{The West Framed Islam within Phobia}

When Spain, Portugal, Britain, France and other imperial countries embarked on a colonial expansion, they developed an ideology to justify the conquest. In the 16th and 17th century, they permitted the exploitation of indigenous people in the New World by arguing that "wild Indians" were idol worshipers who had been ordained by God to be enslaved by Christians. ${ }^{10}$ The enslavement of the Africans was also justified by the book of Genesis. It said that the Africans are cursed (taken from the myth of the Curse of Ham or Canaan) whose skin color was blackened to mark the curse. Thus, even after the African slaves converted to Christianity, they could still continue to be slaves. ${ }^{11}$

The shift from religious justification to "scientific" occurred in the 18th century in the context of Enlightenment and the growth of science. Scientists such as Carl Linnaeus and Johann Friedrich Blumenbach divided humans into various races with different characteristics. The logic that flows from this classification, in terms of colonialism, is that the white Europeans are superior and "the darker

\footnotetext{
Muslim Racism in the UK and Australia before 11 September 2001," Journal of Sociology, Vol. 43, No. 1, pp. 61-86; S. Sayyid and AbdoolKarim Vakil (2011), Thinking through Islamophobia: Global Perspectives, London: Hurst and Co.

${ }^{6}$ Brian Klug (2012), "Islamophobia: A Concept Comes of Age," Ethnicities, Vol. 12, No. 5, pp. 665-681.

${ }^{7}$ Laura Cervi (2020), "Exclusionary Populism and Islamophobia: A Comparative Analysis of Italy and Spain,” Religions, Vol. 11, No. 10, pp. $1-21$.

${ }^{8}$ Samuel P. Huntington (1993), "The Clash of Civilizations?” Foreign Affairs, Vol. 72, No. 3, pp. $22-49$.

${ }^{9}$ Iftikhar H. Malik (2004), Islam and Modernity: Muslims in Europe and the United States, London: Pluto Press, p. 9.

${ }^{10}$ Hans Koning (1993), The Conquest of America: How the Indian Nations Lost Their Continent, New York: Cornerstone Press.

${ }^{11}$ George Fredrickson (2002), Racism: A Short History, Princeton, NJ: Princeton University Press.
} 
black people" and other skin colour as "ugly" and, at best, "half-civilized." 12 Racism, as an ideology to justify slavery and conquest, developed around this time. At the end of the 19th century, when the English poet Rudyard Kipling wrote "The Burden of White People," he only reinforced the widespread idea. Kipling writes about the inherent superiority of the West and how it is their "burden" to civilize and tame the people in the East and Islam. Characterized as "half-demon, half child," the colonized is seen as not only evil or savage but also like a child, and therefore, needs protection. It was originally published in the Times of London with the subtitle, "United States and Philippine Islands," and was Kipling's call to the United States to take on the same responsibilities as Britain. ${ }^{13}$

In short, orientalists argue that "the West" is a dynamic, complex and ever-changing society, whereas "the East," and especially the Islamic world, are static, barbaric, and despotic, and therefore, require Western Intervention to bring progressive change. This Classic Orientalist mindset greatly helped France and Britain in their conquest of the Middle East and North Africa, which were predominantly Muslim, in the 18th and 19th centuries. The United States, which encountered these territories as an imperial power only a short time later (after World War II), inherited a lot of this discourse. Hollywood, for example originates from an exotic Eastern view that emerged from romanticism, artistic movement and 18th century literature. Eastern imagery presented by the Romans "is characterized by fierce scenes in a series of wild colors; harems, domes and white towers, refreshing springs under palm trees, and captivated women forced to submit to their lustful kidnappers." ${ }^{14}$ Hollywood absorbs these images and makes the Middle East a land of sheiks, oasis, camels, deserts, dancing girls, and in general a place mired in backwardness. ${ }^{15}$ Movies such as Sheikh and the Thief of Baghdad reinforces the stereotype of Arabs as having a poor culture, sexually distorted and depraved, and basically filled with violence. ${ }^{16}$

After World War II, the United States devised a strategy to foster Islamists who would act as allies against secular nationalist and communist forces in various Muslim countries. ${ }^{17}$ But, as Dreyfuss has observed, "Leading US politicians are misguided stereotypical prisoners." 18 From FDR to Eisenhower, the views towards Arabs and people from the Middle East are full of prejudice and racism. Edward Said argues that "Islam" became a politically and negatively charged term in the 1970s after the United States experienced and oil shortage at the beginning of the decade and the 1979 Iranian revolution that brought Islamic government Ayatollah Khomeini to power. ${ }^{19}$ This particular "Islamic" construction, is part of a fiction and ideology, and they are not representative to Islam. The term "Islam" promoted as ideology, refers to a backward, unchanging, and static world that demands US intervention and "modernization." Orientalism today is influenced by these kind of phobia and took in the term "Islamophobia" or fear/ hatred of Islam and Muslims. The main form in the public is the threat of terrorist activities that should be put forward, for example, in the famous PBS documentary Jihad in America. Another form of phobia is the alleged plan of Muslims to take over the United States as in David Gubautz's book, Muslim Mafia: Inside the Underworld Secret which conspired to Islamize America; the book was an inspiration and callings for several members of the GOP House that the Council on American-Islamic Relations were investigated for trying to infiltrate the government. ${ }^{20}$

In the academic field, the West and the United States in particular, made many study programs that included those in the Middle East. Many Orientalist scholars moved from Europe to the United States to take up several positions at various universities. One of the scholars is Bernard Lewis, who coined the phrase "clash of civilizations." Lewis wrote in the 1950s, that he sets himself the task of describing "the qualities or tendencies in Islam, in Islamic civilization and society might facilitate or hinder the progress of Communism." 21 These modern Orientalists sees Islam as a monolithic religion and Muslims as static individuals who do not change. Then in 1990, in an essay titled The roots of Muslim Rage,

\footnotetext{
${ }^{12}$ Ibid.

${ }^{13}$ David Spurr (1993), The Rhetoric of Empire: Colonial Discourse in Journalism, Travel Writing, and Imperial Administration, Durham: Duke University Press, p. 113.

${ }^{14}$ Maxime Rodinson (2006), Europe and the Mystique of Islam, London: I.B. Tauris, p. 59.

15 Jack G. Shaheen (2001), Reel Bad Arabs: How Hollywood Vilifies a People, Northampton, MA: Interlink Publishing Group.

${ }^{16}$ Douglas Little (2002), American Orientalism: The United States and the Middle East since 1945, Chapel Hill: University of North Carolina Press.

${ }^{17}$ Robert Dreyfus (2005), Devil's Game: How the United States Helped Unleash Fundamentalist Islam, New York: Henry Holt.

${ }^{18}$ Ibid., p. 8.

${ }^{19}$ Edward W. Said (1997), Covering Islam, New York: Vintage Books.

${ }^{20}$ Glenn Greenwald (2009), "GOP House members call for investigation of Muslim political activity," retrieved 14th December 2020, https://www.salon.com/2009/10/15/investigation/.

${ }^{21}$ Quoted in Zachary Lockman (2004), Contending Visions of the Middle East: The History and Politics of Orientalism, Cambridge, UK: Cambridge University Press, p. 131.
} 
Lewis wrote about the essence of Islamic culture that contradicted the West, in what he calls "the clash of civilizations." Samuel Huntington, who has done much to popularize this idea, argues that "Western ideas about individualism, liberalism, constitutionalism, human rights, equality, freedom, rule of law, democracy, free market, separation of the church and state, often have little resonance in Islamic society." 22 To Huntington, the post-Cold War world is characterized by "alignments which are determined by culture and civilization" ${ }^{23}$ and provides an overview of "Muslim inclinations towards violent conflict." 24 This will lead to the clashes of civilization. In short, non-reconstructed Orientalism reaffirmed itself in the 1990s. But as Gerghes notes, this view is a minority among the political elite during this period; only after $9 / 11$ is when we would begin to see it rising.

\section{Rhetoric of Hatred towards Islam}

The five rhetoric of hatred and fear of Islam and Muslims in Spain, and in the West, can generally be described in these following five popular expressions. ${ }^{25}$ First, Islam is a monolithic religion. A lot of Islamophobic rhetoric today tries to vilify Arabs in particular. However, not all Muslims are from Arab, and not all Arabs are Muslims. Arabs are the people who speak Arabic, share certain common cultural traditions, and claim the same Arabic identity. ${ }^{26}$ Geographically speaking, the Arab world is traditionally divided into two parts (the East and the West of the Nile river): the Maghreb or the West consists of Morocco, Libya, Algeria, Tunisia, Sudan, and etc., and the Mashreq or the East which includes Egypt, Syria, Lebanon, and all the Eastern countries, but it does not include Iran. Due to the linguistic and cultural differences, people from Iran and Turkey are not considered as Arabs. In short, Islam is practiced by a lot of people with ethnical, linguistical, national, cultural, political and economic differences. However, these following frames describe the Muslim view, which is essential.

Secondly, Islam is a sexist religion. The veil in Islam has been the topic or subject of many controversies over the past few years. It is seen everywhere as a symbol of oppression of Muslim women. Veils have been banned, ridiculed, or used as a reason for the argument that is accepted immediately, about the need for the Spanish society (and the West in general) to save Muslim women. Not found in this argument is the voice and opinion of Muslim women who can construct alternative narratives, such as talks about those who wear them based on the choices they made consciously. Like I said in another part, such a move would require diverting the field to a location where Muslim women are seen as a victim to somewhere where they are seen as an agent. ${ }^{27}$ The latter was then carefully avoided by political elites and the media to construct a convincing narrative of the rescue. During and after the invasion of Afghanistan, a couple of political figures, including Laura Bush, Cherie Blair, George Bush, Donald Rumsfeld, Colin Powell, and others argued that the United States are obligated to uphold women's rights in Afghanistan and to eradicate the Taliban regime. ${ }^{28}$ Subtle references to "our" cultures and values, as can be seen in the previous quotations, serve to ground the rescue narrative within the framework of the clash of civilizations. A similar logic was used when France passed a ban for headscarfs (written as a ban on all religious symbols in schools) on the basis of the argument that this would "liberate" Muslim women. In reality, however, is that neither Afghan women nor French Muslims are liberated by these actions. At present, Afghan women are no better than before the war, especially those in rural areas. ${ }^{29}$ In France, that ban just causes more discrimination and exclusion of Muslim women. ${ }^{30}$ However, most of the public discourse in the United States and Europe continues to uphold the myth that Muslim women are victims that need to be rescued and that the West, an enlightened entity, can play a progressive role in a context like that.

\footnotetext{
${ }^{22}$ Quoted in John L. Esposito (1999), The Islamic Threat: Myth or Reality, $3^{\text {rd }}$ edition, New York: Oxford University Press.

${ }^{23}$ Samuel Huntington (1996), The Clash of Civilization and the Remaking of World Order, New York: Simon and Schuster, p. 125.

${ }^{24}$ Ibid., p. 258.

${ }^{25}$ Deepa Kumar (2010), "Framing Islam: The Resurgence of Orientalism during the Bush II Era," Journal of Communication Inquiry, Vol. 34, No. 3, pp. $254-277$.

${ }^{26}$ Maxime Rodinson (1979), The Arabs, Chicago: University of Chicago Press.

${ }^{27}$ Deepa Kumar (2008), "Heroes, Victims, and Veils: Women's Liberation and the Rhetoric of Empire Post 9/11," Forum on Public Policy: Journal of the Oxford Roundtable, pp. 23-32.

${ }^{28}$ Carol A. Stabile and Deepa Kumar (2005), "Unveiling Imperialism: Media, Gender, and the War on Afghanistan," Media, Culture, and Society, Vol. 27, No. 5, pp. 765-782.

${ }^{29}$ Deepa Kumar (2009), "Why the US has to go" (interview with the Afghan Member of Parliament Malalai Joya)," retrieved 14 ${ }^{\text {th }}$ December 2020, http://socialistworker.org/2009/11/10/why-us-has-go.

30 Naima Bouteldja (2005), "French hijab ban: One year on. Red Pepper Europe," retrieved 14 ${ }^{\text {th }}$ December 2020, http://www.redpepper.org.uk/french_hijab_ban_one_year_c.
} 
Third, Muslims are seen as people who do not have the ability to master science. Andalusia is the center of the triumph of Islam. There are many Muslim scientists and scientific developments there. However, Spain and the Western society would like to systematically erase the historical legacy of Muslim science and rationality in Europe. This is proven on September 12, 2006, when Pope Benedict XVI gave his very famous speech in Rustenburg, where he compared Catholicism with "rationality" and Islam with violence and the lack of rationality. Quoting a 14th-century Byzantine emperor, he stated that when a religion (like Islam) was propagated through violence, it was contrary to common sense and also against nature, because "not acting without rationale (or logic) is contradictive to the nature of God." ${ }^{31}$ In making this argument, the Pope joined a long line of orientalists who argued that reason, rationality, and science, were foreign to the Islamic world. Ernest Renan, who championed science and reason, said in an essay published in 1883 with the title "Islam and Science: "Early Islam and Arabs claim to be hostile to scientific and philosophical passion." 32 The Pope's speech is deeply rooted in Orientalist myths; he presents a specific vision about a rational and enlightened "West," and obscures the history of Christian violence. He, therefore, quotes Byzantine Emperor Manuel II Paleologus, who said, "Show me that what Muhammad brought is something new, and there you will only find evil and inhumane things, like his command to spreading the faith by the sword in which he preached about." 33

Fourth, Islam is a religion of violence. One of the clearest visual depictions of the argument that Islam basically is a violent religion can be found in cartoons of Nabi Muhammad that are published in the Danish newspaper, Jyllands-Posten. This cartoon shows the Prophet with a bomb in his turban. The logic that follows from this illustration is that Islam emerged with violence as its core. But few, if any, editors of newspapers in the United States agree with this logic when they reproduced this cartoon. As part of the culture of common sense, they avoid critical surveillance. Likewise, the US World News and Report presents an overview of Islamic history titled "Spreading Faith: A Chronology," which internalizes this logic. This chronology starts with the birth of Muhammad in 570 and ends with the $9 / 11$ tragedy, as if to say that there is an unbroken line of continuity between the two events. ${ }^{34}$

This tendency to link Islam with violence continues under the Obama administration. After the incident in Fort Hood in November 2009, when Major Nidal Hassan pointed a gun at his colleagues and killed 13 of them, most medias explained by linking Islam with violence. ${ }^{35}$ Tunku Varadarajan even went a step further by suggesting that Major Nidal's actions is better understandable through the phrase "Muslim," which describes a process in which a Muslim "discards apparent integration into the American society and chooses to justify his religion in a messianic act of violence against fellow Americans." ${ }^{36}$ The point of Varadarajan's argument is that Muslims are like a ticking time bomb programmed by their religion to inevitably turn to violence. ${ }^{37} \mathrm{~A}$ comparative study of media coverage on the implementation of abortion providers Dr. George Tiller in the hands of Christian extremists with events in Fort Hood, found that "it is very common to find links in the press between Islam and terror, while Christianity is freed from the driving factors in terrorist acts." 38

The claim that Islam was spread through war is, in fact, accurate. In the two decades after the Prophet's death in $632 \mathrm{CE}$, Muslim armies defeated two of their neighboring great empires, the Byzantine and Persian (Sassanid) empires; conquering most of their land; and built the Islamic Empire. Muslim troops were able to defeat these two powerful empires due to the continuing war between Byzantium and Persia the whole of the previous century that has made their people weary. In fact, some villages even welcomed the Muslim troops. Once in power, and not like their orthodox Christian counterparts who

\footnotetext{
31 Benedict XVI (2006), "Lecture of the Holy Father," retrieved 14 ${ }^{\text {th }}$ December 2020, http://news.bbc.co.uk/2/shared/bsp/hi/pdfs/15_09_06_pope.pdf.

${ }^{32}$ Cited in Mahmood Mamdani (2005), Good Muslim Bad Muslim: America, the Cold War and the Roots of Terror, USA: Three Leaves Press, p. 45 .

${ }^{33}$ Benedict XVI, "Lecture of the Holy Father."

${ }^{34}$ Secrets of Islam (Collector's Edition), U.S. News and World Report, August 23, 2005, 32-33.

${ }^{35}$ History.com Editors (2009), "Army major kills 13 people in Fort Hood shooting spree," retrieved 14 ${ }^{\text {th }}$ December 2020, https://www.history.com/this-day-in-history/army-major-kills-13-people-in-fort-hood-shooting-spree; Deepa Kumar (2009), "Islamophobia and the war on Afghanistan. Lecture at New York University," retrieved 14 ${ }^{\text {th }}$ December 2020, https://www.youtube.com/watch?v=pFRNtSZ7QG0andlc=z12iyrro1nnphz0ek22ihd0ilw2lhxd4304.

${ }^{36}$ T. Varadarajan (2009), "Going Muslim," retrieved 14 ${ }^{\text {th }}$ December 2020, http://www.forbes.com/2009/11/08/fort-hood-nidal-malik-hasanmuslims-opinions-columnists-tunkuvaradarajan.html.

${ }^{37}$ Deepa Kumar, "Islamophobia and the war on Afghanistan."

${ }^{38}$ History.com Editors, "Army major kills 13 people in Fort Hood shooting spree."
} 
persecuted heretics and ruled through fear, intimidation, and terror, Muslim invaders gave their people a choice to convert to Islam or pay taxes. ${ }^{39}$

Christianity has also risen to dominance through conquest and repentance, first in the Roman world and then to neighboring regions in Europe, Armenia, Arab, East Africa, and Central Asia ${ }^{40}$ The crusade was another round of violence in the history of Christianity; religious wars waged by Christian Europeans from the 11th to the 13th century were partly driven by the religious passion to seize Jerusalem and partly by the desire to plunder the region's wealth. ${ }^{41}$ During the First Crusade of 1099, the Crusaders carried out mass killings after taking over Jerusalem, killing almost the entire population of Muslim men, women and children. The Jewish, who fought alongside the Muslims to defend the city, were also not spared. The Crusaders burned a synagogue in which the Jewish took shelter and made sure that each of them burned to death. ${ }^{42}$ The same level of brutality can be seen throughout the Third Crusade, when King Richard from England (Richard the Lionheart) beheaded thousands of people in cold blood before their soldiers after the battle. On the contrary, after the Egyptian Emperor, Saladin, regained Jerusalem from the Crusaders, acts of revenge and violence towards the Crusaders were banned. Moreover, the Jewish were given state money to rebuild the synagogue, and the churches were left untouched. ${ }^{43}$ This is consistent with how the Islamic kingdom treats Christians and Jews. During the 500 years of Islamic rule in Jerusalem, from the 7th century to the 11th century, Christian churches were largely untouched, and the Jews were allowed to return and resettle in the area. This harmony was interrupted by the Crusades, when Christian Crusades destroyed the area and spread chaos, destroyed synagogues and mosques, and killed Jews and Muslims. ${ }^{44}$

Finally, the West is a propagator of democracy, and Muslims are the propagator of terrorism. The classic version of this framework states that the Islamic civilization is not capable of accepting democracy and can only produce despotism. Therefore Muslims are static and unchanging societies, and this becomes the West's obligation to civilize, modernize and democratize them. This "Caucasian" argument has been used, in various forms and disguise, of all European powers in the past. The United States has also used this argument, once in the case of Iraq, and then Afghanistan. The reality, however, is very different from that rhetoric. Instead of spreading democracy, the United States are more consistent in destabilizing the democratic movement and replacing it with dictatorship. ${ }^{45}$ After World War II, the Middle East and North Africa were rocked by the struggle for national liberation. Between 1932 and 1962, Egypt, Iraq, Syria, Lebanon, Libya, Morocco, Tunisia and Aljazeera, all succeeded in obtaining various levels of autonomy from colonial rulers, France and Britain. In the wake of this struggle was a broad atmosphere for reformation, change in the region, and the emergence of political and social powers. Secular Arab nationalism gained support, but socialist and communist parties competed for political influence.

\title{
Politic of Islamophobia: Shadow of Reconquista and Inquisition
}

\begin{abstract}
Over the centuries, there has been an incessant struggle in Spain's imagination between 'Maurophobia'/Islamophobia and 'Maurophilia'/ Islamophilia which, to date, has settled on the overriding negative image of Muslims in general and Moroccans in particular (Arabians, Arabs, Moslems, Saracens, Mohammedans, Berbers, Turks, Moors, Maghrebis, Islamists, and so on). ${ }^{46}$
\end{abstract}

After the 9/11 tragedy, it turns out that not only America has the tendency to the emergence of Islamophobia, this disease affected Europe Pasca in general, specifically Spain. It is suspected to be

\footnotetext{
${ }^{39}$ Arthur Goldschmidt, Jr. and Lawrence Davidson (2006), A Concise History of the Middle East, $8^{\text {th }}$ edition, Boulder, Co: Westview Press.

${ }^{40}$ Zachary Lockman (2004), Contending Visions of the Middle East: The History and Politics of Orientalism, Cambridge, UK: Cambridge University Press.

${ }^{41}$ Goldschmidt and Davidson, A Concise History of the Middle East.

${ }^{42}$ Tariq Ali (2002), Clash of fundamentalisms, New York: Verso.

${ }^{43}$ Andrew Curry (2005), "The first holy war," retrieved $14^{\text {th }}$ December 2020, https://www.usnews.com/topics/author/curry_andrew.

${ }^{44}$ Goldschmidt and Davidson, A Concise History of the Middle East.

${ }^{45}$ William Blum (2000), Rogue State, Monroe, ME: Common Courage Press; Stephen Kinzer (2006), Overthrow: America's Century of Regime Change from Hawaii to Iraq, New York: Henry Holt; Sidney Lens (2003), The Forging of the American Empire, London: Haymarket Books and Pluto Press.

46 Felipe Maraña Marcos (2019), “Islamophobia in Spain in 2019," retrieved 14 ${ }^{\text {th }}$ December 2020, https://ethicaljournalismnetwork.org/resources/publications/saving-the-news/islamophobia-spain-2019. Maurophobia is a specific hatred aimed at Moroccans and those who identify with Morocco. Maurophilia and Islamophilia are the opposite, that is, unconditional love for Morocco or Islam.
} 
more obvious in the political world. The right-wing regional party in Spain regained a major victory in national elections.

Relations between the VOX Party, which was led by Santiago Abascal, and the Muslim community has never been easy. In 2015, when VOX (which was founded in late December 2013) was still a minority as a political power and relatively is not that well known by the people of Spain. Abascal and the leader of the Islamic Commision of Spain at the time, Natalia Andújar, was also involved in an intense verbal confrontation. The origin of this confrontation was an article that was written by the leader of VOX that was published in an online newspaper Libertad Digital titled "Caballo de Troya" (Trojan Horse). In this article, he warns people of the potential dangers of the Spanish government policies that gives Muslim students access to Islamic teachings in primary schools. Abascal argues that this action is a "dangerous privilege." Andújar considers Abascal's view as "xenophobia and Islamophobia that promotes antidemocratic values." Abascal insists with his argument and continues to repeat his warning. ${ }^{47}$

Three years after that incident, VOX's stance towards Muslims and Islam did not change. During the recent elections in Andalusia in late November 2018, the main issue in various Party speeches was "Reconquista" (Reconquest). Although a few parties deny that these speeches remind them of the Christian Crusades towards Muslims, the term Reconquista itself historically refers to the expulsion of Muslims by Queen Isabel --which later became a role model for Abascal as a politician-- and the Catholic King Fernando, whom both succeeded in ending the Islamic empire ruling of Granada after dominating for eight centuries, mainly in Andalusia. The connotation from the word 'reconquest' then becomes the principle of populist struggles for the VOX party.

In 2016, the Muslim Community represents 2,6\% growth, 1,180,000 $0^{48}$ and at the end of 2019, there were approximately 2.1 million of whom more than 879,808 are citizens of Spain. ${ }^{49}$ It was clear that the promises that were made by VOX in their election campaign are of special importance to them. In 2018, the President of VOX believes that there is no danger in Islamophobia in Spain. The most obvious danger is Islamophilia.

VOX claims that they dislike the Islamic pillars because they view Islam as less strict in terms of separation between religion and politics, and also how Muslims view the world (for example, their treatment towards women). Abascal, like many other citizens, judge Islam (that is practiced by over 1.8 billion followers worldwide $)^{50}$ based on the homogenous perspective without accepting the potential for differences among Muslims. They also tend to find it difficult to understand the cultural diversity, religious and political practices carried out in the name of Islam.

What becomes a problem is that Abascal is not a regular citizen, but also (and most importantly) the leader of a political party, so his choice of words had an impact on whether hundreds of thousands of the Spanish people reject or trust Muslims among them. Right before the election in Andalusia (that started in the fall of 2018), he stated in a lecture at Gran Canaria that immigrants from South America would be preferred over those coming from Islamic countries. He said this because he was afraid that $4 \%$ of the Muslims that lived in Spain can "become a problem." Although the type of problem in his mind was never clarified to the public. During a meeting in November 2018 with 700 people all cramped in a hotel in Cordoba city, the party candidates for that province, Alejandro Hernández Valdés, stated that they will fight against the people who want to change cathedrals into mosques. Although seeing it through historical facts, it happened the other way around, where mosques were turned into cathedrals.

In a radio interview with a popular journalism, Carlos Herrera, just a few days before the election, Abascal argued that immigration has to be controlled linked to economic demands of the state and also "consistent to the compatibility with our culture," therefore "we don't have to change our traditions or

\footnotetext{
${ }^{47}$ Carmen Aguilera-Carnerero (2019), "VOX and the Spanish Muslim Community: the New "Reconquista" of Spain," retrieved 15 ${ }^{\text {th }}$ December 2020, https://www.opendemocracy.net/en/can-europe-make-it/vox-and-spanish-muslim-community-new-reconquista-of-spa/.

48 Pew Research Center (2017), "Europe's Growing Muslim Population," retrieved 15 ${ }^{\text {th }}$ April 2021, https://www.pewforum.org/2017/11/29/europes-growing-muslim-population/.

49 Statista (2020), "Number of Muslims in Spain in 2019, by nationality," retrieved 15 th $^{\text {April }}$ 2021, https://www.statista.com/statistics/989902/muslims-in-spain-by-

nationality/\#: :text=At $\% 20$ the $\% 20$ end $\% 20$ of\%202019,thousand $\% 20$ believers $\% 20 \mathrm{in} \% 20 \mathrm{both} \% 20$ cases.

${ }^{50}$ There were 1.8 billion Muslims in the world as of 2015 - roughly $24 \%$ of the global population - according to a Pew Research Center estimate. Pew Research Center (2017), "Muslims and Islam: Key findings in the U.S. and around the world," retrieved 15 $5^{\text {th }}$ April 2021, https://www.pewresearch.org/fact-tank/2017/08/09/muslims-and-islam-key-findings-in-the-u-s-and-around-the-world/.
} 
our menus at school." He is referring to the act to include halal menus in primary schools if there's a minimum of 10 students that need it, as guaranteed in the Cooperation Agreement that was signed by the government and the Islamic Commission of Spain in 1992. In mid-December 2018, after the Andalusian elections and the unexpected victory of VOX, an independent Catalan politician, Najat Driouech, a Muslim woman who does not wear a hijab, calls VOX's ideology as "chauvinist" in the Catalan Parliament. Abascal's reaction on Twitter was quick and inappropriate. Najat Driouech was told to check her religion first before calling him a Chauvinist. More or less, this is how the proliferation of racist and Islamophobic comments made by the people who follow him on social media. The classic Islamophobic climate spread from views that consider Islam as oppressing women (to wear hijab), silencing them to express their opinions, or that they were not born in Spain although having Spanish citizenship, is once again an insult towards Islam that mostly emerges in the public.

So, the relations between VOX and the Muslim community has always been complicated since the very start. Muslims are one of the biggest religious minorities in Spain and their status as a Spanish citizen currently seems to be under the threat of the VOX party's political weapon. There has always been a problem between the people of Spain towards Muslims even way before VOX entered the political arena. However, the most explicit recent Islamophobic attacks, that is familiar in a wider European context, is something that is fairly new to the political world in Spain.

Their strategy to win the election is through campaigning Islamophobia. As stated by Flora Hasting, that "Muscular men are riding a stallion across a village landscape. A piano is playing in the background. Where are all these people? The title of VOX's political campaign tells you: "Reconquista will start in Andalusia lands." The slogan of this campaign was very controversial. This was a part of the strategy used to secure the victory of 12 seats for the right-wing parties in the Andalusian region in last year's elections. VOX became one out of five parties that competed in the Spanish elections. They were one of the parties that experienced an unexpected growth. ${ }^{51}$

Reconquista, that means "reconquest," refers to the history of the conquest of Christian Iberia on Spanish Muslims that ended in 1492. The political reformation that was proposed by VOX caused this historical relevance to be clear: if chosen, the party claims that they would end the migration of Muslims while calming the 'threat' towards the national identity of Spain in the growth of Islam. Other than that, they would also end abortion which is funded by the state, and also repeal gay marriage laws.

The history of the Christian-Muslim conflict in the Middle Ages has shaped the repertoire of symbolism among the right-wing parties. For eight centuries, Spain was ruled by Muslim rulers known as the Moors. In $711 \mathrm{CE}$, the ruling Umayyah dynasty traveled from Syria to Spain, and in the end conquered the Visigothic territory, which was then renamed as Andalusia. Spain currently is filled with what's left of history, which consists of the architecture of the Moors and even words with Arabic origins in the Spanish language..$^{52}$

The secretary-general of the VOX party, Javier Ortega Smith, state in 2016 that "the enemy of Europe is the Islamic invasion." With the end of Reconquista in 1492, the national identity of Spain started to emerge. The Catholic Monarchy, as a new ruler, took strong and systematic measures to falsify it. Those who are not Catholics were not to be accepted as part of the Spanish society in the new social order. This process finally leads to the eviction of the Jewish and Muslim populations in the European peninsula. ${ }^{53}$

Spanish ethnonationalism continued in the 20th century. Former Spanish dictator, General Franco has given a deep power, and banned any religion to save Catholicism and force standardization of what was considered as the core of Spanish culture, from the Castilian language to even bull-fighting. Franco's Spanish nationalism was defined as an effort to be against all Jews and Muslims in the country, like the use of the Reconquista symbolism in their propaganda. Franco's rhetoric even combined the myths of 'Moors threats' towards Spain and the 'threat' of the Eastern European communism. With Franco's

\footnotetext{
${ }^{51}$ See Flora Hasting (2019), “The New Spanish Islamophobia," retrieved 15 $5^{\text {th }}$ April 2021, https://newint.org/features/2019/04/26/new-spanishislamophobia.

${ }^{52}$ Ibid.

${ }^{53} \mathrm{Ibid}$.
} 
death in 1975, Spain officially dissolved their explicit authoritarian structure. However, the history of ethnonationalism still haunts in public places. ${ }^{54}$

Apart of the believe of Morocco as backward state, many citizen of Spain regards the entrance of Moroccan migrants since 1970s as re-Islamization of the country. In addition to current cases of Islamophobia, there is a 'Moros y Cristianos' festival in Spain commemorated every year re-enacting the Muslim-Christian conflict. Every year, people will go out and dress as 'Moro' or 'Christianos' and do the scene of the final Reconquista battle where they establish the Middle Age stereotypes of the Moor as fanatics. In Alcoy the festival takes place from April $21^{\text {st }}$ to April $24^{\text {th }} .{ }^{55}$ Although the ritual is considered as mere commemoration of past conflict, the Vox spoke-persons often promote the idea that Muslim is the anti-thesis of all ideas of 'Spain' during this ritual.

Moroccans are the second-largest minority in Spain. Many of the Spanish Moroccan communities are ancestrally linked to the historical Muslim population in Spain. In a market in Cordoba, called 'Morro's Mercado' by local residents, Tariq, a Moroccan trader told me about the strong anti-Muslim prejudice he confessed in Andalusia: "They think that there are only camels and deserts in Morocco," he said. Apart from the perception of Morocco as an "underdeveloped" country, some of the Spanish community even felt that the entry of Moroccan immigrants into Spain since the 1970s as a process to 'reIslamization' the country. Beyond the more striking cases of Islamophobia, there is a Spanish tradition that revisits this Christian-Muslim division. ${ }^{56}$ Every year, individuals throughout Spain dress in 'Moro' or 'Christianos' and re-enact the last battle of Reconquista, in which the medieval stereotypes of the Moors as religious fanatics increased through Caricature Carnival. Although this cultural ritual is considered to commemorate disputes over the past, VOX spokespersons called for a "new Reconquista" by celebrating this cultural ritual in a darker spectrum, and going beyond that to spread the idea that Muslims are antithetical to everything 'Spanish'. ${ }^{57}$

The Reconquista revitalization is not a new development in Spanish politics. In an effort to garner support for the Iraq War, José Aznar, the former prime minister of the Spanish Conservatives, explicitly linked the medieval Moorish nation to Al-Qaeda. In 2004, he stated that 'Spain's problem with AlQaeda started with the invasion of the Moors', which was rejected due to a 'successful Reconquista'. The Vox Political Party built this rhetoric. The president of the party, Santiago Abascal, ${ }^{58}$ petitioned for an Andalusia celebration day that is aimed to celebrate the Reconquista victory in 1492. At a meeting in Seville, Abascal stated that he wanted the Andalusian Catholic Monarchy to oppose Blas Infante. Infante is a libertarian socialist writer known as the father of Andalusian nationalism. In the early 20th century, he sought to restore the Spanish heritage of coexistence between the Jewish, Muslims, and medieval Christians to become a contemporary reality.

The choices of words that were used in this party's political speech are filled with Islamophobia. Javier Ortega Smith, Vox's secretary-general, stated in 2016 that 'Europe's enemy is the invasion of Islam'. Vox's president, Santiago Abascal, reunited with Smith and stated in an interview last year that the Spanish Muslim community will be a 'problem'. The political reform that was proposed by the party includes banning Islamic education and halal food in public schools all over Spain.

This is all part of the European phenomenon. In the week after the shooting of a mosque in New Zealand on March 15th, 2019, the number of anti-Muslims hate crimes reported across Britain increased by 593 percent. These attacks were triggered by the stereotypes that emerged across the continent, ranging from the perception that Muslims were jihadists and even perceiving Muslim immigrants as an inevitable threat to Western values.

Vox's anti-Muslim stance has helped win the support of Europe's largest right-wing political groups. In 2017, Abascal claims to have close relations with Marine Le Pen, leader of the French ultraconservative populist party to protect 'European Christians' hand in hand. Le Pen, along with Geert Wilders, party leader of the Dutch right-wing party, has openly supported Vox by expressing their hopes

\footnotetext{
${ }^{54}$ Ibid

${ }^{55}$ Spanish Fiestas (n.d.), "Moros y Cristianos Festival," retrieved 15 $5^{\text {th }}$ April 2021, https://www.spanish-fiestas.com/festivals/moros-ycristianos/.

${ }^{56}$ Flora Hasting, "The New Spanish Islamophobia."

${ }^{57}$ Spanish Fiestas, "Moros y Cristianos Festival."

${ }^{58}$ Ibid.
} 
that the party will get a seat in the European parliamentary elections in May of 2017. ${ }^{59}$ The cooperation that is developing among the European right-wing parties has and will continue to strengthen the institutional roots of Islamophobia throughout the continent.

Maurophobia (hatred towards Moroccans) and Islamophobia are developing in contemporary Spain. In Spain, Muslims are considered as the main domestic enemy since the 8th century, since their arrival in the Iberian Peninsula, up until 1492, and then followed by the Reconquista crimes and Inquisition; for hundreds of year's confrontation between the Spanish Empire and the Ottoman Empire in the name of Christianity, up until the Battle of Lepanto in 1591. For the next three centuries were the war with Muslim pirates in the Mediterranean, and until the Spanish Peace Treaty with Tunis in 1791; and for the last two centuries, which has been triggered by conflicts with Marocco. The main cause of the conflict between Spain and its Southern neighbors began from the territory occupied by Spain in North Africa. This inevitable friction between two neighboring countries that are separated by one of the largest political and cultural gaps and per capita income (10:1). Islamophobia was triggered by the historical tension rooted from the shared threat of terrorism by Al Qaeda, ISIS and their franchise since 9/11. The joint alliance with the United States and strong economic, legal and police bilateral ties established over the past 30 years have eased that tension.

With Franco's death in 1975 and the consolidation of democracy, ${ }^{60}$ the new values of solidarity and tolerance are rooted. Along with that is the emerging efforts to eradicate offensive hatred and hostility towards Muslims, especially in the media, in school curriculums and in political discourse. Also, about a third of Muslim immigrants in Spain have arrived since migrants began to be imported--not exported-in the 1990s.

This spirit of tolerance is supported through the tradition of close ties between the Spanish government -- under Franco's dictatorship and with the monarchy which replaced him as the leader of the state -and the main Arab regimes through Spain's mass support for the Palestinian struggle (Palestine has become the beneficiary of Spanish development aid for some time) and the equal rejection of the Iraq invasion in 2003, although the Spanish President, José María Aznar, who ruled since 1996 until 2004, was George Bush's biggest ally in Europe in this invasion together with Tony Blair. Even to this day, millions of the Spanish people still believe that the terrorist attacks on March $11^{\text {th }}$, 2004, as one of the worst attacks in Europe (193 people died and 2,000 injured), ${ }^{61}$ was mostly the result of direct retaliation by Muslim extremists for Aznar's support of Bush. One of Spain's foremost experts in this case, Professor Fernando Reinres, refutes this claim.

In dozens of texts, videos and audio clips, the Al Qaeda leaders--and later followed by ISIS--have confirmed that Spain was included as target for their terrorist attacks, considering it as 'occupied land' (al-Andalus), due to relations with Israel that has been established and continue to grow since 1986 and / or commitment as a loyal ally of the US and becoming NATO's main force in Europe and the European Union (EU). ${ }^{62}$ The fact is, Spain has participated in all foreign operations by the EU and almost every NATO operation for the past 20 years. For the Muslim extremist propaganda, this becomes a good enough reason to justify the Madrid attacks in 2004 and Catalonia attacks in 2017. Every attack is always followed by Islamophobic cases in Spain, although the numbers are not as high in comparison with cases in the US after 9/11, in Britain after 7/7 in London, and in France 2012 after the Charlie Hebdo shooting in Paris and attacks at Nice and Nantes.

In its final quarterly report in October-December 2018 period, ${ }^{63}$ the Observatory of Islamophobia in Spanish Media analyzed articles written by Spanish journalists and two of Spain's biggest newspapers, El País dan La Razón, and two largest news agencies, EFE and Europa Press in their digital edition.

\footnotetext{
${ }^{59}$ Flora Hasting, "The New Spanish Islamophobia."

${ }^{60}$ Antonio Moreno Juste (2015), "The European Economic Community and the End of the Franco Regime: the September 1975 Crisis," Cahiers de la Méditerranée, Vol. 90, pp. 1-21.

61 VOI (2021), "March 11 In History: The Madrid Train Bombing That Confused Spain," retrieved 15" April 2021, https://voi.id/en/memori/38364/march-11-in-history-the-madrid-train-bombing-that-confused-spain.

62 Time (2017), "Why Spain Has Once Again Become a Target for Jihadists," retrieved 15" April 2021, https://time.com/4904858/jihadism-in-spain-history/; Ronald D. Asmus and Bruce P. Jackson (2005), "Does Israel Belong In the EU and NATO?" Policy Review, pp. 47-56.

${ }^{63}$ European Institute of the Mediterranean (2019), "Change is within our Reach: Islamophobia in the Media," retrieved 16 ${ }^{\text {th }}$ April 2021, https://www.iemed.org/publicacions-en/historic-de-publicacions/coedicions/un-cambio-a-nuestro-alcance.-islamofobia-en-los-medios; Instituto Europeo del Mediterráneo (IEMed) (2019), Un Cambio a Nuestro Alcance: Islamofobia en los Medios, Al-Fanar Fundacion.
} 
With eight terms (Islam, Muslim, Jihad, Jihad, Jihad, Islam, Islam, Islamophobia) and eight indicators from Runnymede Trust (based on the effects from articles), researchers have concluded that almost one in every four articles about Islam that was published in Spain still contains Islamophobia. The level of Islamophobia is more evident in agencies than in newspapers, more in news articles rather than in opinion pieces, and more in conservative press (La Razon). It also grew more in news and / or images related by referring to the terms radicalization, terrorism, veils, refugees and women. Nevertheless, the results of 2018 still reveal a strong existence of Islamophobia in Spanish media. Islam and Muslim is still being related mostly to negative elements. Although an insignificant improvement is observed, this happens in $73 \%$ of the articles, and in 2017 it was almost in the $90 \%$ of articles. Among these negative elements, terrorism dominates in 2018 the information on Islam: more than $60 \%$ of articles about Islam deal with this topic, followed by the issue of radicalization.

\section{Figure 1. Islamophobia in the Spanish Media}

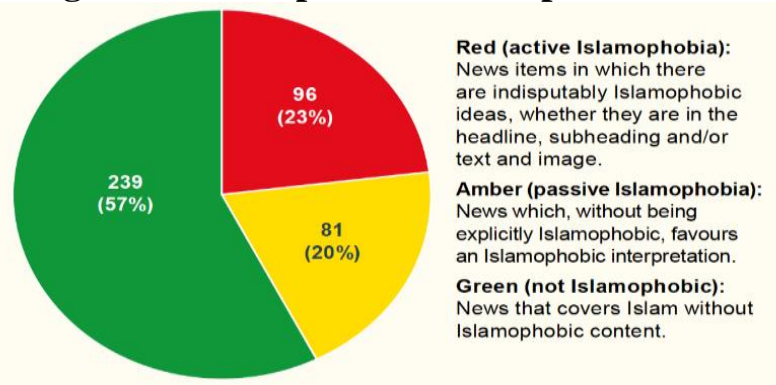

Source: Observatory of Islamophobia in the Spanish Media

Words are not the only problem. In 2017, The Citizen Platform Against Islamophobia in Spain just published "Annual Report on Islamophobia in Spain 2017." The Platform has registered 546 cases of Islamophobia, 160 offline cases and 386 online cases. See the detail figure below. ${ }^{64}$ Catalonia leads with 51 cases $(31.8 \%)$, followed by Andalusia with 22 cases (13.7\%), the Valencia Community with 20 cases (12.5\%), and Madrid with 17 cases (10.6\%). Television stations are reportedly worse than printed media and the most conservative media, while social media is considered to be much worse than traditional media. From 269 reports of online hate speeches that were analyzed by Platform in 2017, a majority of the total of 135 cases were on Facebook (100), Twitter (12), WhatsApp (11) dan Youtube (5), Change.Org (4), ForoCoches (2), and Instagram (1). However, this is only the tip of the iceberg given that only a small portion of cyberhate cases is reported on social networks. ${ }^{65}$

Figure 2. Annual Report on Islamophobia in Spain, 2017

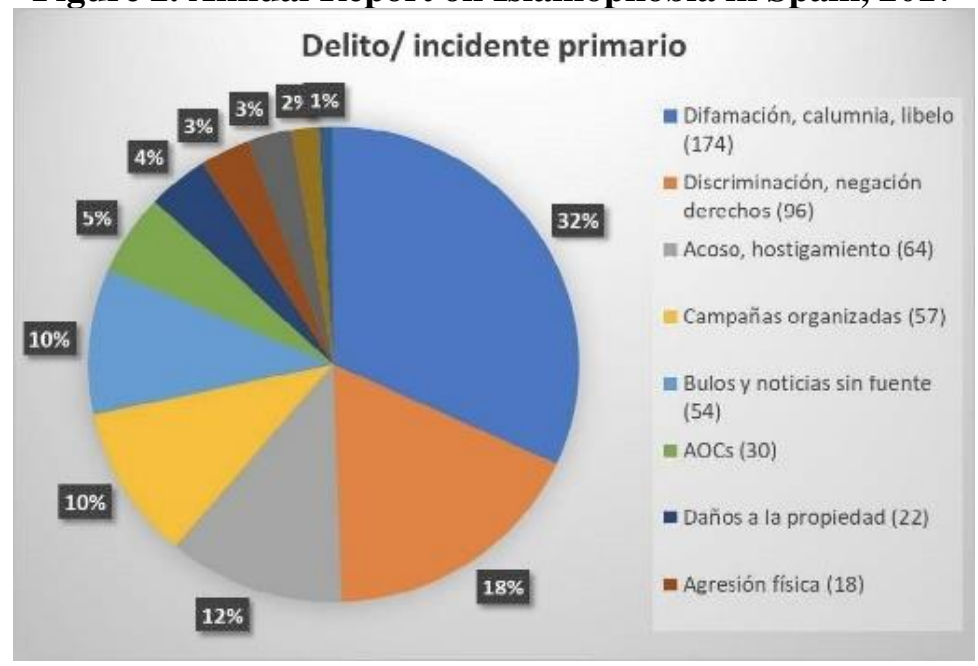

The PCCI reports the following wrong behaviors by the media: lack of sources in very grave accusations; linking Islam and terrorism, abundance of generalizations towards Islam and Muslim; stigmatization of Muslims in the headlines through the use of the terms "second" and "third" generation

\footnotetext{
${ }^{64}$ Fundación de Cultura Islámica (2018), “The PCCI publishes its “Annual Report on Islamophobia in Spain 2017,” retrieved 15 th April 2021, http://twistislamophobia.org/en/2018/03/08/the-pcci-publishes-its-annual-report-on-islamophobia-in-spain-2017/.

65 Hasan Esen (2018), "Spain sees over 500 Islamophobic incidents last year," retrieved 15 April 2021, https://www.aa.com.tr/en/europe/spain-sees-over-500-islamophobic-incidents-last-year/1078511.
} 
to refer to immigrants from majority Muslim countries; the services covered by the agreement, such as halal menus or religious lessons in the schools, are usually presented as "demands by the Muslim community; treating the two million Muslims living in Spain as foreigners; lack of knowledge or information on the collaboration agreements signed between the State and the Spanish Islamic Commission in 1992."

In the presentation of the report, Bárbara Ruiz Berajano, who is responsible for the Platform's International Relations, summarizes that this serious problem of Islamophobia in the Spanish media under five titles: 1) The emerging of Islamophobia biases among party leaders or political groups, specifically the extreme right-wing and neo-Nazis; 2) The constant attacks on mosques; 3) Campaigns that are held to be against the opening of mosques; 4) Increase of Islamophobia towards women; and 5) Increased discourse which denies the Islamic historical heritage in Spain. ${ }^{67}$

\section{Conclusion}

Islamophobia in the Spanish context generally resembles the Western tendency in facing the challenges of terrorism after the $9 / 11$ tragedy. The war on terrorism that has always been promoted by the West reflects the new face of the classic orientalism tradition which was motivated by religious impulses that hide behind claims of political and economic interests. The tendency of Islamophobia in Spain is also strengthened along with the rise of emerging political parties or populist political rhetoric that is easily found in the US or West Europe. What makes Spain different is that this hatred for Islam and Muslims were triggered by the historical reminders of the dominance of the Islamic rule for 7 centuries. Populist politicians use the Reconquista and Inquisition themes as a way to arouse the anti-Islamic and antiMoroccan (Maurophilia) sentiments.

These anti-Islamic themes gained the support of both the printed and electronic media. Therefore, efforts to reduce the Islamophobia rhetoric urgently needs a guide on how news about Islam and Muslims needs to be treated equally as any other news. Implying that the efforts used to reduce Islamophobia needs to be accompanied with better training for journalists to be more balanced in tracking news sources along with a wider range and variety of informants. Also, for journalists to be able to differentiate amid confusion between information and opinion, have a better screening system and to verify facts both in forms of text or images. Along with knowing how to establish closer cooperation between civil and political institutions for better quality and conditions. Journalists and politicians also need to make use of the same media network to counterattack Islamophobia effectively, unfortunately not many utilize this.

\section{References}

Aguilera-Carnerero, Carmen (2019), "VOX and the Spanish Muslim Community: the New "Reconquista" of Spain," retrieved $15^{\text {th }}$ December 2020, https://www.opendemocracy.net/en/caneurope-make-it/vox-and-spanish-muslim-community-new-reconquista-of-spa/.

Ali, Tariq (2002), Clash of fundamentalisms, New York: Verso.

Allen, Chris (2010), Islamophobia, Farnham: Ashgate.

Asmus, Ronald D. and Jackson, Bruce P. (2005), “Does Israel Belong In the EU and NATO?” Policy Review, 47-56.

Benedict XVI (2006), "Lecture of the Holy Father," retrieved $14^{\text {th }}$ December 2020, http://news.bbc.co.uk/2/shared/bsp/hi/pdfs/15_09_06_pope.pdf.

Blum, William (2000), Rogue State, Monroe, ME: Common Courage Press.

\footnotetext{
${ }^{66}$ Fundación de Cultura Islámica (2018), "The PCCI publishes its "Annual Report on Islamophobia in Spain 2017."

67 Sisumma (2018), "Presentation of the report Islamophobia in Spain, 2017," retrieved 15 $15^{\text {th }}$ April 2021, http://www.sisumma.com/event/presentation-of-the-report-islamophobia-in-spain-2017/.
} 
Bouteldja, Naima (2005), "French hijab ban: One year on. Red Pepper Europe," retrieved 14 December 2020, http://www.redpepper.org.uk/french_hijab_ban_one_year_c.

Cervi, Laura (2020), "Exclusionary Populism and Islamophobia: A Comparative Analysis of Italy and Spain," Religions, Vol. 11, No. 10, 1-21.

Cesari, Jocelyne (2004), When Islam and Democracy Meet: Muslims in Europe and in the United States, New York, NY: Palgrave Macmillan.

Curry, Andrew (2005), "The first holy war," retrieved $14^{\text {th }}$ December 2020, https://www.usnews.com/topics/author/curry_andrew.

Dreyfus, Robert (2005), Devil's Game: How the United States Helped Unleash Fundamentalist Islam, New York: Henry Holt.

Esposito, John L (1999), The Islamic Threat: Myth or Reality, $3^{\text {rd }}$ edition, New York: Oxford University Press.

Esposito, John L. and Ibrahim Kalin (2011), Islamophobia: The Challenge of Pluralism in the 21st Century, Oxford: Oxford University Press.

European Institute of the Mediterranean (2019), "Change is within our Reach: Islamophobia in the Media," retrieved $16^{\text {th }}$ April 2021, https://www.iemed.org/publicacions-en/historic-depublicacions/coedicions/un-cambio-a-nuestro-alcance.-islamofobia-en-los-medios.

Fredrickson, George (2002), Racism: A Short History, Princeton, NJ: Princeton University Press.

Fundación de Cultura Islámica (2018), "The PCCI publishes its "Annual Report on Islamophobia in Spain 2017," retrieved 15 ${ }^{\text {th }}$ April 2021, http://twistislamophobia.org/en/2018/03/08/the-pcci-publishesits-annual-report-on-islamophobia-in-spain-2017/.

Goldschmidt, Arthur Jr. and Lawrence Davidson (2006), A Concise History of the Middle East, $8^{\text {th }}$ edition, Boulder, Co: Westview Press.

Greenwald, Glenn (2009), "GOP House members call for investigation of Muslim political activity," retrieved $14^{\text {th }}$ December 2020, https://www.salon.com/2009/10/15/investigation/.

Gunduz, Zuhal Yesilyurt (2010), "The European Union at 50 - Xenophobia, Islamophobia and the Rise of the Radical Right," Journal of Muslim Minority Affairs Vol. 30, No. 1, 35-47.

Hasan Esen (2018), "Spain sees over 500 Islamophobic incidents last year," retrieved $15^{\text {th }}$ April 2021, https://www.aa.com.tr/en/europe/spain-sees-over-500-islamophobic-incidents-last-year/1078511.

Hasting, Flora, (2019), "The New Spanish Islamophobia," retrieved $15^{\text {th }}$ April 2021, https://newint.org/features/2019/04/26/new-spanish-islamophobia.

History.com Editors (2009), "Army major kills 13 people in Fort Hood shooting spree," retrieved $14^{\text {th }}$ December 2020 , https://www.history.com/this-day-in-history/army-major-kills-13people-in-fort-hood-shooting-spree.

Huntington, Samuel P. (1993), “The Clash of Civilizations?” Foreign Affairs, Vol. 72, No. 3, 22-49.

Huntington, Samuel P. (1996), The Clash of Civilization and the Remaking of World Order, New York: Simon and Schuster.

Instituto Europeo del Mediterráneo (IEMed) (2019), Un Cambio a Nuestro Alcance: Islamofobia en los Medios, Al-Fanar Fundacion. 
Juste, Antonio Moreno (2015), "The European Economic Community and the End of the Franco Regime: the September 1975 Crisis," Cahiers de la Méditerranée, Vol. 90, 1-21.

Kinzer, Stephen (2006), Overthrow: America's Century of Regime Change from Hawaii to Iraq, New York: Henry Holt.

Klug, Brian (2012), “Islamophobia: A Concept Comes of Age,” Ethnicities Vol. 12, No. 5, 665-681.

Koning, Hans (1993), The Conquest of America: How the Indian Nations Lost Their Continent, New York: Monly Review Press.

Kumar, Deepa (2008), "Heroes, Victims, and Veils: Women's Liberation and the Rhetoric of Empire Post 9/11," Forum on Public Policy: Journal of the Oxford Roundtable, 23-32.

Kumar, Deepa (2009), "Islamophobia and the war on Afghanistan. Lecture at New York University," retrieved $14^{\text {th }} \quad$ December 2020, https://www.youtube.com/watch?v=pFRNtSZ7QG0andlc=z12iyrro1nnphz0ek22ihd0ilw2lhxd4304.

Kumar, Deepa (2009), "Why the US has to go" (interview with the Afghan Member of Parliament Malalai Joya)," retrieved $14^{\text {th }}$ December 2020, http://socialistworker.org/2009/11/10/why-us-has-go.

Kumar, Deepa (2010), "Framing Islam: The Resurgence of Orientalism during the Bush II Era," Journal of Communication Inquiry, Vol. 34, No. 3, 254 -277.

Lens, Sidney (2003), The Forging of the American Empire, London: Haymarket Books \& Pluto Press.

Little, Douglas (2002), American Orientalism: The United States and the Middle East since 1945, Chapel Hill: University of North Carolina Press.

Lockman, Zachary (2004), Contending visions of the Middle East: The History and Politics of Orientalism, Cambridge, UK: Cambridge University Press.

Malik, Iftikhar H (2004), Islam and Modernity: Muslims in Europe and the United States, London: Pluto Press.

Mamdani, Mahmood (2005), Good Muslim Bad Muslim: America, the Cold War and the Roots of Terror, USA: Three Leaves Press.

Marcos, Felipe Maraña (2019), "Islamophobia in Spain in 2019," retrieved 14 ${ }^{\text {th }}$ December 2020, https://ethicaljournalismnetwork.org/resources/publications/saving-the-news/islamophobia-spain2019.

Pew Research Center (2017), "Europe's Growing Muslim Population," retrieved 15 ${ }^{\text {th }}$ April 2021, https://www.pewforum.org/2017/11/29/europes-growing-muslim-population/.

Pew Research Center (2017), "Muslims and Islam: Key findings in the U.S. and around the world," retrieved $15^{\text {th }}$ April 2021, https://www.pewresearch.org/fact-tank/2017/08/09/muslims-and-islam-keyfindings-in-the-u-s-and-around-the-world/.

Poynting, Scott and Mason, Victoria (2007), "The resistible rise of Islamophobia: Anti-Muslim racism in the UK and Australia before 11 September 2001," Journal of Sociology Vol. 43, No. 1, 61-86.

Rodinson, Maxime (1979), The Arabs, Chicago: University of Chicago Press.

Rodinson, Maxime (2006), Europe and the Mystique of Islam, London: I.B. Tauris.

Said, Edaward W (1997), Covering Islam, New York: Vintage Books. 
Sayyid, S. and AbdoolKarim Vakil (2011), Thinking through Islamophobia: Global Perspectives, London: Hurst and Co.

Secrets of Islam (Collector's Edition). U.S. News and World Report, $23^{\text {rd }}$ August 2005, 32-33.

Shaheen, Jack G. (2001), Reel Bad Arabs: How Hollywood Vilifies a People, Northampton, MA: Interlink Publishing Group.

Sisumma (2018), "Presentation of the report Islamophobia in Spain, 2017," retrieved $15^{\text {th }}$ April 2021, http://www.sisumma.com/event/presentation-of-the-report-islamophobia-in-spain-2017/.

Spanish Fiestas (n.d.), "Moros y Cristianos Festival," retrieved $15^{\text {th }}$ April 2021, https://www.spanishfiestas.com/festivals/moros-y-cristianos/.

Spurr, David (1993), The Rhetoric of Empire: Colonial Discourse in Journalism, Travel Writing, and Imperial Administration, Durham: Duke University Press.

Stabile, Carol A. \& Deepa Kumar (2005), "Unveiling Imperialism: Media, Gender, and the War on Afghanistan," Media, Culture, and Society, Vol. 27, No. 5, 765-782.

Statista (2020), "Number of Muslims in Spain in 2019, by nationality," retrieved $15^{\text {th }}$ April 2021, https://www.statista.com/statistics/989902/muslims-in-spain-bynationality/\#: :text=At \%20the\%20end\%20of\%202019,thousand\%20believers\%20in\%20both\%20cas es.

The Runnymede Trust (1997), "Islamophobia: A Challenge for Us All: Summary," retrieved 14 December 2020, https://www.runnymedetrust.org/uploads/publications/pdfs/islamophobia.pdf.

Time (2017), "Why Spain Has Once Again Become a Target for Jihadists," retrieved $15^{\text {th }}$ April 2021, https://time.com/4904858/jihadism-in-spain-history/.

Varadarajan, T. (2009), “Going Muslim," retrieved $14^{\text {th }}$ December 2020, http://www.forbes.com/2009/1 1/08/fort-hood-nidal-malik-hasan-muslims-opinions-columniststunkuvaradarajan.html.

VOI (2021), "March 11 In History: The Madrid Train Bombing That Confused Spain," retrieved 15 April 2021, https://voi.id/en/memori/38364/march-11-in-history-the-madrid-train-bombing-thatconfused-spain. 
Journal of Al-Tamaddun, Vol. 16 (1), 2021, 65-79 